\title{
The effect of alcohol ingestion on exhaled nitric oxide
}

\author{
D.H. Yates, S.A. Kharitonov, R.A. Robbins, P.S. Thomas, P.J. Barnes
}

The effect of alcohol ingestion on exhaled nitric oxide. D.H. Yates, S.A. Kharitonov, R.A. Robbins, P.S. Thomas, P.J. Barnes. CERS Journals Ltd 1996.

ABSTRACT: The concentration of nitric oxide (NO) is increased in the exhaled air of patients with inflammatory lung diseases, including asthma, possibly reflecting cytokine-mediated chronic airway inflammation. Endogenous NO is generated from L-arginine by the action of several types of NO synthase (NOS). NOS have structural similarities with cytochrome $\mathbf{P 4 5 0}$ reductases. Alcohol decreases exhaled NO in animals, but this has not previously been investigated in man.

We studied the effect of alcohol ingestion in nine asthmatic and 12 normal subjects, measuring the peak concentration of exhaled NO using a modified chemiluminescence analyser.

A significant decrement in NO occurred in asthmatic patients (mean \pm SEM before ethanol $204 \pm 58$ to $158 \pm 59$ parts per billion ( $p p b)$ after ethanol; $p<0.02$ ), without significant change in the normal subjects $(122 \pm 14$ to $114 \pm 15 \mathrm{ppb})$.

Thus, in our study, alcohol decreased exhaled nitric oxide in asthmatic subjects but not in normal individuals. This may reflect preferential action on inducible nitric oxide synthase which is expressed in asthmatic airways. An inhibitory effect of ethanol on inducible nitric oxide synthase may contribute towards the effect of alcohol in asthma.

Eur Respir J., 1996, 9, 1130-1133.
Dept of Thoracic Medicine, National Heart \& Lung Institute, London, UK.

Correspondence: D.H. Yates

Dept of Thoracic Medicine

Concord Hospital

Concord

NSW 2139

Australia

Keywords: Alcohol

asthma

nitric oxide

Received: October 131995

Accepted after revision February 51996
The gas nitric oxide (NO) is now recognized to regulate a wide variety of pulmonary functions and to play a key role in host defence and in the pathophysiology of airway diseases $[1,2]$. Nitric oxide is formed in the lungs and the presence of NO has been detected in the exhaled air of several species, including man [3]. Exhaled NO is increased in inflammatory lung disorders, such as asthma and bronchiectasis $[4,5]$. Probable sources of exhaled NO include airway epithelium and inflammatory cells, such as pulmonary macrophages. The nose may also generate NO, which may be inhaled into the lower respiratory tract [6], but it is unlikely that this represents the sole source of exhaled NO in asthma [4].

$\mathrm{NO}$ is synthesized from the amino acid L-arginine by the action of nitric oxide synthases (NOS), which exist in several isoforms [7]. Constitutive NOS (cNOS) is basally expressed in endothelial and neuronal cells, and occurs in at least two forms. Inducible NOS (iNOS) is expressed in a wide variety of inflammatory cells, and can also be induced in endothelial cells and smooth muscle [8]. iNOS is expressed after exposure to endotoxin and proinflammatory cytokines, resulting in the formation of much larger amounts of NO than activation of cNOS. iNOS but not cNOS is sensitive to inhibition by glucocorticosteroids [9]. Elevated levels of exhaled NO in asthmatic patients probably reflect increased iNOS expression secondary to the generation of proinflammatory cytokines $[4,10]$.

The enzymes synthesizing NO show similarities with cytochrome $\mathrm{P} 450$ reductases. Of the two major domains of NOS, the first shows significant (38\%) sequence identity with reduced form (nicotinamide adenine dinucleotide phosphate (NADPH)) cytochrome P450 reductase [11]. Ethanol is metabolized by the P450 system, and could therefore affect the $\mathrm{L}$-arginine/NO pathway. Intravenous alcohol has been reported to decrease exhaled NO in animals when infused in concentrations relevant to man [12]. Alcohol may also act as a mild bronchodilator in certain asthmatic patients [13], and be beneficial in the treatment of status asthmaticus [14]. We therefore hypothesized that alcohol might alter exhaled NO levels in man, possibly due to an effect on NOS expression, and this might differ between normal and asthmatic subjects.

\section{Subjects and methods}

\section{Subjects}

We studied 21 volunteers (5 females and 16 males; mean \pm SEM age $37 \pm 2 \mathrm{yrs}$ ), including nine asthmatic patients (table 1). Asthmatic subjects had a history of wheezing or chest tightness and had been previously diagnosed by a doctor as having asthma. All symptoms were wellcontrolled. Normal subjects had no past or present respiratory symptoms, had normal lung function and chest examination on screening, and took no oral medication. There was no significant difference in age between asthmatic and normal subjects. Six of the asthmatic patients were using inhaled glucocorticosteroids (mean dose 1.2 mg budesonide daily) and all used inhaled $\beta_{2}$-agonists as needed. None was suffering from an upper respiratory tract infection, or had received a course of oral steroids 
Table 1. - Characteristics of asthmatic and normal subjects

\begin{tabular}{|c|c|c|c|c|c|}
\hline $\begin{array}{l}\mathrm{Pt} \\
\text { No. }\end{array}$ & $\begin{array}{l}\text { Age } \\
\text { yrs }\end{array}$ & Sex & Atopy & $\begin{array}{l}\text { FEV1 } \\
\%\end{array}$ & Medication \\
\hline \multicolumn{6}{|c|}{ Asthmatic subjects } \\
\hline 1 & 48 & M & + & 94 & Budesonide $800 \mu \mathrm{g} b . d$. \\
\hline 2 & 33 & M & + & 79 & Budesonide $400 \mu \mathrm{g}$ b.d. \\
\hline 3 & 50 & M & + & 82 & $\begin{array}{l}\text { Budesonide } 800 \mu \mathrm{g} \text { b.d., } \\
\text { Salmeterol } 50 \mu \mathrm{g} \text { b.d. }\end{array}$ \\
\hline 4 & 24 & $\mathrm{M}$ & + & 58 & $\begin{array}{l}\text { Budesonide } 800 \mu \mathrm{g} \text { b.d. } \\
\text { Salmeterol } 50 \mu \mathrm{g} \mathrm{b.d.}\end{array}$ \\
\hline 5 & 36 & M & + & 93 & Salbutamol p.r.n. \\
\hline 6 & 33 & M & + & 78 & Budesonide $400 \mu \mathrm{g}$ b.d. \\
\hline 7 & 32 & $\mathrm{~F}$ & + & 97 & Salbutamol p.r.n \\
\hline 8 & 38 & M & + & 49 & $\begin{array}{l}\text { Budesonide } 800 \mu \mathrm{g} \text { b.d. } \\
\text { Salmeterol } 50 \mu \mathrm{g} \text { b.d. }\end{array}$ \\
\hline 9 & 26 & M & + & 103 & Salbutamol p.r.n. \\
\hline \multicolumn{6}{|c|}{ Normal subjects } \\
\hline 1 & 40 & M & - & 104 & - \\
\hline 2 & 36 & $\mathrm{~F}$ & + & 103 & - \\
\hline 3 & 36 & M & + & 79 & - \\
\hline 4 & 37 & M & + & 114 & - \\
\hline 5 & 36 & M & - & 92 & Sulfasalazine (topical) \\
\hline 6 & 32 & $\mathrm{~F}$ & - & 95 & - \\
\hline 7 & 33 & M & - & 92 & \\
\hline 8 & 33 & $\mathrm{~F}$ & + & 90 & Budesonide (nasal) \\
\hline 9 & 45 & M & + & 102 & - \\
\hline 10 & 42 & $\mathrm{~F}$ & - & 111 & - \\
\hline 11 & 22 & M & + & 109 & - \\
\hline 12 & 28 & M & - & 105 & - \\
\hline
\end{tabular}

Pt: patient; M: male; F: female.

within the previous 3 months. Mean \pm SEM forced expiratory volume in one second (FEV1) in the asthmatic patients was $81 \pm 6 \%$ of predicted. The study was approved by the Royal Brompton National Heart \& Lung Hospital Ethics Committee and all subjects gave written informed consent.

\section{Measurement of exhaled NO}

Nitric oxide was measured using a chemiluminescence analyser (Dasibi Environmental Corp. Model, Glendale, CA, USA), specially adapted to allow on-line recording of NO concentration, as described previously [4]. After flushing the analyser with NO-free compressed air, subjects were instructed to inspire to total lung capacity (TLC) and to perform a slow vital capacity manoeuvre over 30-60 s into wide-bore Teflon tubing. NO was sampled continuously. Results were displayed on a chart recorder and compared with the signal produced from a calibration mixture of NO in nitrogen ( 89 parts per billion $(\mathrm{ppb})$ ). Three reproducible recordings were made in succession at $2 \mathrm{~min}$ intervals and the highest of the readings was used in the analysis. The area under the curve of concentration traces was highly correlated with the peak value $(p<0.01)$ [4], and peak values were therefore used in analysis of results. NO was measured at baseline (after at least 15 min of rest) and again 15 min after ingestion of alcohol. Baseline and post-alcohol breath alcohol levels were measured by means of a Lion Alcolmeter SM S-D2 (Lion Laboratories PLC) at least 8 min after the last alcohol drink. Fifty millilitres of vodka, $45 \%$ by volume (approx $18 \mathrm{~g}$ of alcohol), were consumed after initial measurements.

\section{Statistical analysis}

Repeated exhaled NO levels were analysed by Friedman's analysis for nonparametric data, and a p-value of less than 0.05 was considered to be significant. Differences between groups were analysed by the Mann-Whitney test. Data are expressed in the text as means \pm standard error of the mean (SEM). Individual values and group medians are shown in figure 1 .

\section{Results}

All subjects completed the study, and no adverse effects were reported. Asthmatic subjects had a higher exhaled NO than normal subjects, although this did not reach statistical significance. Asthmatic subjects showed a fall in exhaled NO (mean \pm SEM $204 \pm 58$ to $158 \pm 59 \mathrm{ppb} ; \mathrm{p}<0.02$ ) after alcohol ingestion. In normal subjects, although a drop was observed $(122 \pm 14$ to $114 \pm 15 \mathrm{ppb})$, this was small and did not reach statistical significance (fig. 1a and 1b). Breath alcohol levels rose from a baseline of 0 to mean $136.4 \pm 32$ units $(\mathrm{p}<0.01$; data not shown). No difference was observed in breath alcohol levels between asthmatic and normal subjects.

\section{Discussion}

Our study has demonstrated that ingestion of ethanol can inhibit exhaled nitric oxide production in man. The fact that levels did not decrease in normal subjects and yet fell significantly in asthmatic subjects would be consistent with a greater effect of alcohol on iNOS than on 
a)

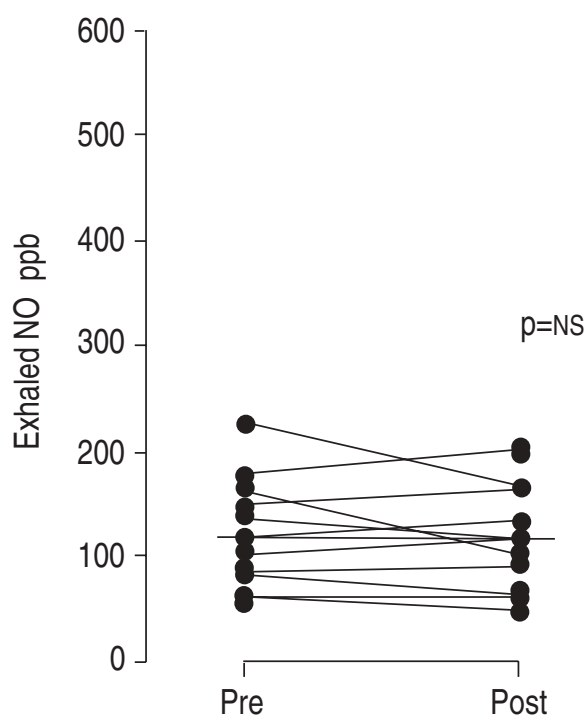

b)

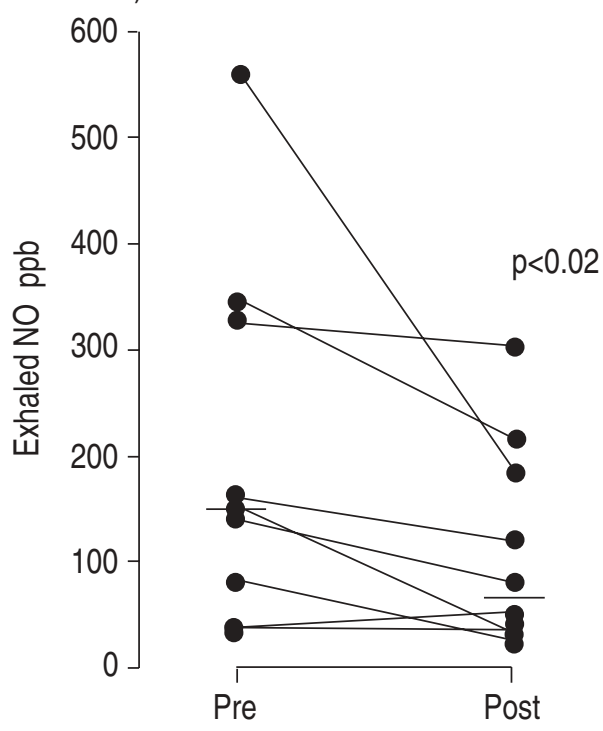

Fig. 1. - Exhaled nitric oxide (NO) levels, measured in parts per billion (ppb) before (Pre) and after (Post) ingestion of alcohol. Individual values and group medians are shown. a) Normal subjects $(\mathrm{n}=12)$; b) Asthmatic patients $(\mathrm{n}=9)$.

the cNOS expressed in normal human respiratory epithelial cells [10].

An increase in iNOS expression may account for the increase in exhaled NO in asthma, possibly induced by cytokines such as tumour necrosis factor- $\alpha$ (TNF- $\alpha$ ), interleukin-1 $\beta$ (IL-1 $\beta)$ and interferon- $\gamma(\mathrm{IFN}-\gamma)$ produced in asthmatic inflammation $[4,15]$. Like glucocorticosteroids, alcohol may also have an inhibitory effect on NO generation.

Intravenous alcohol decreases exhaled NO in tracheotomized rabbits in a dose-dependent manner [12], and has been shown to decrease iNOS expression in rat alveolar macrophages [16]. In contrast to the effects of argininederived NOS inhibitors, such as $\mathrm{N}^{\mathrm{G}}$-monomethyl-L-arginine (NMMA), the effect of ethanol in animals is not reversible by arginine infusion, implying that alcohol may act noncompetitively. L-NMMA decreases the lipopolysaccharide (LPS)-induced increase in NO levels in rat alveolar macrophages but has no effect on iNOS gene expression. Ethanol, however, decreases not only NO levels but also messenger ribonucleic acid (mRNA) expression for iNOS, again suggesting a different mechanism of action [16].

The decrease in exhaled NO that we observed in asthmatic patients is of interest in view of reported effects of ingested alcohol in asthma. Although NO has weak bronchodilator effects in asthmatic patients [17], it also has inflammatory effects, including vasodilatation and increased plasma exudation, and may amplify asthmatic inflammation [1]. In vitro, ethanol is known to inhibit antigen-induced bronchoconstriction and mediator release in lungs from sensitized guinea-pigs [18]. Regular oral administration of alcohol to guinea-pigs results in decreased bronchial reactivity [19]. Asthmatic patients with a documented early asthmatic response provoked by an alcoholic beverage do not react to ethyl alcohol, and bronchoconstriction can be prevented by pretreatment with disodium cromoglycate, implying a type 1 mastcell mediated effect of additives rather than alcohol itself
[20]. Where beneficial, ingested alcohol has also been reported to confer greater benefit in those with more severe disease [13].

Ethanol may have a greater inhibitory effect on inducible nitric oxide synthase, which is expressed in the epithelium of asthmatic patients, than on the basally expressed constitutive nitric oxide synthase of normal individuals. Ethanol may act noncompetitively and selectively on inducible nitric oxide synthase, possibly via a different mechanism from that of glucocorticosteroids. Exploration of the relationship between alcohol and nitric oxide may provide insight into disease mechanisms and further research in this area is needed.

Acknowledgements: The authors thank the Medical Research Council for support. DHY is supported by Astra Draco, Lund, Sweden, SAK by the National Asthma Campaign, London, and RAR by the University of Nebraska, USA.

\section{References}

1. Barnes PJ, Belvisi MG. Nitric oxide and lung disease. Thorax 1993; 48: 1034-1043.

2. Gaston B, Drazen JM, Loscalzo J, Stamler JS. The biology of nitrogen oxides in the airways. Am J Respir Crit Care Med 1994; 149: 538-551.

3. Gustafsson LE, Leone AM, Persson MG, Wiklund NP, Moncada S. Endogenous nitric oxide is present in the exhaled air of rabbits, guinea-pigs and humans. Biochem Biophys Res Commun 1991; 181(2): 852-857.

4. Kharitonov SA, Yates DH, Robbins RA, Logan-Sinclair $\mathrm{R}$, Shinebourne E, Barnes PJ. Increased nitric oxide in exhaled air of asthmatic patients. Lancet 1994; 343: 133-135.

5. Kharitonov SA, Wells AU, O'Connor BJ, et al. Elevated levels of exhaled nitric oxide in bronchiectasis. Am J Respir Crit Care Med 1995; 151: 1889-1893.

6. Gerlach H, Rossaint R, Pappert D, Knorr M, Falke K. 
Autoinhalation of nitric oxide after endogenous synthesis in the nasopharynx. Lancet 1994; 343: 518-519.

7. Zapol WM, Rimar S, Gilis N, Marletta M, Bosken C. Nitric oxide and the lung. Am J Respir Crit Care Med 1994; 149: 1375-1380.

8. Moncada S, Higgs A. The L-arginine-nitric oxide pathway. $N$ Engl J Med 1993; 329: 2002-2012.

9. Di Rosa M, Radomski M, Carnuccio R, Moncada S. Glucocorticosteroids inhibit the expression of an inducible but not the constitutive nitric oxide synthase in vascular endothelial cells. Proc Natl Acad Sci USA 1990; 87: 10043-10049.

10. Hamid Q, Springall DR, Riveros-Moreno V, et al. Induction of nitric oxide synthase in asthma. Lancet 1993; 342: 1510-1513.

11. White KA, Marletta M. Nitric oxide is a cytochrome P450 type hemoprotein. Biochemistry 1992; 31: 66276630.

12. Persson MG, Gustafsson LE. Ethanol can inhibit nitric oxide production. Eur J Pharmacol 1992; 224: 99-100.

13. Ayres J, Clark TJH. Alcohol in asthma and the bronchoconstrictor effect of chlorpropamide. Br J Dis Chest 1982; 76: 79-87.

14. Brown EA. The use of intravenous ethyl alcohol in the treatment of status asthmaticus. Ann Allergy 1947; 5: 193-195.

15. Yates DH, Kharitonov SA, Thomas PS, Barnes PJ. Effect of a nitric synthase inhibitor and a glucocorticosteroid on exhaled nitric oxide. Am J Respir Crit Care Med 1995; 152: 892-896.

16. Greenberg SS, Xie J, Kolls J, Summer W, Nelson S. Ethanol selectively suppresses gene expression for inducible nitric oxide synthase II in lung phagocytes and decrea-ses lung clearance of $K$. pneumoniae. Am J Respir Crit Care Med 1994; 149: A2120.

17. Hogman M, Frostell CG, Hedenstrom H, Hedenstierna G. Inhalation of nitric oxide modulates adult human bronchial tone. Am Rev Respir Dis 1993; 148: 1474-1478.

18. Fleisch JH. Inhibition of antigen-induced mediator release from guinea-pig lungs by alcohols. Am Rev Respir Dis 1976; 114: 1107.

19. Debreczeni LA, Huszar E, Barat E, Vertes CH. Bronchial reactivity of alcohol pretreated or unilaterally pulmonectomized guinea-pigs. Eur Respir J 1991; 4 (Suppl. 4): p1472.

20. Breslin ABX, Hendrick DJ, Pepys J. Effect of disodium cromoglycate on asthmatic reactions to alcoholic beverages. Clin Allergy 1973; 3: 71-82. 